\title{
Transcending Boundaries: Daily Express Correspondent Annie Christitch's Reporting from First World War Serbia
}

\begin{abstract}
Among the female war reporters of the First World War, Annie Christitch stands out as a journalist, lecturer and Catholic suffragist whose biography and career transcended national boundaries. Of Irish-Serbian descent, she was raised in a renowned family in Belgrade and St Petersburg, went to university in London and became fluent in several languages. During the war, she acted as correspondent for the London Daily Express and as a nurse and relief worker in Serbia, where she was subsequently detained by the Austro-Hungarian occupying forces. Christitch produced intimate eyewitness accounts that helped spread knowledge about the appalling war conditions in Serbia, Britain's smallest ally. In 1915, she raised money and equipment for Serbian hospitals through a campaign in the Daily Express and public lectures in Britain and Ireland. Her war stories were reprinted in newspapers in the United States and the British Empire and newspapers around the world reported on her charitable work in Serbia.
\end{abstract}

\section{Keywords}

First World War, Britain, Serbia, British Empire, United States, female war reporter, transnational journalism

\section{Introduction}

Traditionally, the history of media and communication has been studied from a national perspective and has tended to focus on a single medium, such as newspapers, radio or television. The same holds true for most comparative media studies. These approaches, however, neglect the diverse cross-border and transmedial interactions in media and communication history. ${ }^{1}$ As Marie Cronqvist and Christoph Hilgert argue in their report for the 'Entangled Media Histories' research and teaching network (EMHIS), 
public spheres emerging from mass media communication are never limited to the boundaries of nation states or national media systems, but always stretch across them. Journalists, editors, (...) media content (e.g. ideas, topics, genres) have been travelling around and beyond state borders throughout history. ${ }^{2}$

A key concept employed in entangled media histories is transnational history - the study of 'nongovernmental actors and their interactions across national borders' and of 'the exchange of goods, ideas and knowledge across space. ${ }^{3}$ One possible approach for studying transnational entanglements in media and communication history, attributed to Michele Hilmes, is 'to look for key individuals, people whose careers make them "cultural translators" as they actively move from one national setting to another (...). Exploring the trail that such individuals leave behind can unlock the way that transnationality, and also transmediality, function at ground level. ${ }^{4}$ Another strategy, suggested by Marcel Broersma, is 'to track how newspapers copy each other and how one or two "master texts" on a certain event circulate throughout Europe or even worldwide and are adapted to national contexts. ${ }^{5}$

Following Hilmes' and Broersma's methodologies, this article explores transnational connections in the war reporting of Annie Christitch. ${ }^{6}$ For most of the First World War, she served as a correspondent, nurse and relief worker in Serbia, where she was subsequently detained by the Austro-Hungarian occupying forces. Her accounts of the war in Serbia appeared in the London Daily Express and other British papers and were reprinted in newspapers around the world. Christitch defies the traditional national perspective in media and communication history. Throughout her life and career, she displayed a high degree of geographical mobility and transnational engagement that was not unusual for women of her time. ${ }^{7}$ Of Irish-Serbian descent and educated in Belgrade, St. Petersburg and London, she lived for most of her life in England. Her professional career likewise transcended the nation state. As a Serbian journalist and war reporter writing for British and American publications, as a Catholic women's activist in England and Serbia, as a participant in international women's organisations and as a lecturer travelling in foreign countries, Christitch constantly acted across geographic and cultural borders.

Female war reporting across national and cultural borders was not uncommon during the First World War. For instance, Sofía Casanova, a Galician-Spanish expatriate writer, journalist and social campaigner living in Poland, was the Eastern Europe correspondent for the Madrid daily $A B C$ and wrote more than 220 war reports. Further, women published war accounts not only in their countries of origin but also in the press of foreign countries, thus reaching audiences beyond national and 
cultural boundaries. The Austrian travel writer, photographer and journalist Alice Schalek published in Austrian, German and German-American papers and lectured about the war in Austria and Germany. The German novelist and journalist Thea von Puttkamer, based in Constantinople during the war, published in the German, Hungarian, Turkish and German-American press. ${ }^{8}$

Ultimately, as a woman war reporter in a traditionally male-dominated profession, Annie Christitch also crossed gender boundaries. In Britain, women became journalists and editors early, not only for women's magazines but also for the general press. By 1911, 4 per cent of newspaper owners and publishers and 15 per cent of all writers were women. ${ }^{9}$ As Frank Bösch states, ‘journalism gave women access to an academically and politically informed occupation and allowed them to participate in public life.' Women moved to the top positions in journalism, such as foreign correspondents or editorial writers. ${ }^{10}$ During the First World War, the Milan correspondent of the renowned London Times was a woman, Avice (Avis) Waterman, about whom little is known. Waterman was an American journalist born around 1880 and was formally accredited as war correspondent to the Italian armed forces, undertaking several visits to the Italian front. While her dispatches in The Times remain anonymous, in shorter reprints of her war reports in Australian and New Zealand papers her authorship was acknowledged as “Mrs. Waterman, the “Times” correspondent at Milan'. ${ }^{11}$ Mary Frances Billington, a pioneering English journalist and president of the Society for Women Journalists from 1913 to 1920, was in charge of the women's section of the Daily Telegraph. During the First World War, she visited camps of the Women's Auxiliary Army Corps and Allied military hospitals in France and wrote about women's war work. ${ }^{12}$

Nevertheless, Tim Luckhurst has argued that the First World War 'was reported from an almost exclusively male perspective' and that female war reporters 'were immensely rare exceptions'. ${ }^{13}$ Likewise, Anne Sebba maintains that 'potential women war correspondents had little scope to report either about front-line battles or on the atmosphere behind the lines. ${ }^{14}$ In light of new studies, these statements require qualification. Between 1914 and 1918 a considerable number of women from belligerent and neutral countries reported from all major war theatres for newspapers and magazines. Assessing how many female journalists reported on the First World War is difficult. Exact numbers are not available. Recent research suggests that there were around 45 female war reporters for the United States and 60 for Britain, the British Empire and European countries. ${ }^{15}$ However, these numbers remain rough estimates. Who counted as a war correspondent was not clearly defined, and it is likely that the contributions of many women are still hidden in newspaper archives. 
Few female war reporters were formally accredited by the armed forces. Notable exceptions included Peggy Hull from the US; Thea von Puttkamer from Germany; Alice Schalek and Margit Vészi from Austria-Hungary; and Stefania Türr, Flavia Steno, Annie Vivanti and Barbara Allason from Italy. ${ }^{16}$ More often, female war reporters worked on informal assignments for their newspapers or combined war journalism with nursing or other war-related roles. A case in point is the Swiss novelist, travel writer and journalist Noëlle Roger, who worked as a nurse in a French military hospital near Lyon and published acclaimed articles and books about her experience. Women reported war news from wherever they lived and travelled, and they covered all aspects of the war, from the fighting on the fronts, the stories of wounded soldiers and the destruction of towns and landscapes to the impact of the war on women and children at home. Consequently, they complemented and widened the war images provided by their male counterparts. ${ }^{17}$

In 1916, an American newspaper argued that women were highly suitable for war reporting precisely because " $[\mathrm{m}]$ ost of the war "news" comes from the hospitals and the prison camps, anyway, and the women, of course, have access to these places (...). ${ }^{18}$ Christine Hallett similarly claims that a large body of war news was produced by nurses working in war hospitals and field ambulances. In this transitional space between the front lines and the home front, women were ideally positioned to witness the consequences of industrialised warfare. ${ }^{19}$ Hence, as a woman journalist engaged in nursing and relief work, Annie Christitch was well placed to report on the humanitarian side of the war in Serbia. Her 'feminine' reporting style also corresponded with the aims of her paper, the Daily Express.

The rise of the popular press in Britain around the turn of the $20^{\text {th }}$ century led to a shift in the focus of newspapers. Women readers were now increasingly recognised as commercially important, and appealing to a female audience by 'gendering' the news became a key feature of papers like the Daily Mail and Daily Express. The Daily Express, which published most of Christitch's war reports, was a popular national daily founded in London in 1900 and was one of the first papers to put news on the front page instead of advertising. In addition to general news of politics, foreign affairs and finance, the Daily Express featured political commentary, a women's section, and sports. In 1916 it was bought by Lord Beaverbrook, an influential Canadian-British newspaper publisher and Tory politician, who served in 1918 as the Minister of Information under David Lloyd George and was responsible for propaganda in Allied and neutral countries. While the Daily Express' political orientation was conservative, patriotic and pro-Empire, the paper drew readers from every age and 
social group across the British Isles. It catered to people who, while literate and politically interested, were not deeply educated and were looking for something lighter and more entertaining than the quality press. During the war, the circulation of the Daily Express increased from 295,000 (1914) to 580,000 (1918). ${ }^{20}$ In 1918 it prided itself on having the second-largest circulation of newspapers in London. ${ }^{21}$

From its inception, the Daily Express targeted women as readers. Arthur Pearson, the Daily Express founder, famously instructed his staff: ‘Never forget the cabman's wife'. ${ }^{22}$ The female market was important for the paper in terms of circulation and advertising revenue. Ralph David Blumenfeld, the editor of the Daily Express, believed that women numbered at least half of the readership of daily papers. Hence, following a trend set by the Daily Mail, the Daily Express not only featured a women's section but also included stories of interest to women throughout the paper, written in a conversational tone, to attract female readers. ${ }^{23}$ Although the Daily Express staff was predominantly male, the paper also offered writing opportunities to women journalists. During the First World War, writers such as Annie Christitch, Alice Askew, Evelyn Ross and Hilda M. Love contributed stories focusing on the humanitarian side of the war. $^{24}$

This study argues, first, that Christitch was uniquely placed to report from Serbia for British newspapers due to her transnational biography. Of Irish-Serbian descent, fluent in Serbian and English and accustomed to British media traditions, she was an ideal go-between for different nations and cultures. Her personal networks in Serbia enabled her to work in the country during the war and to communicate her first-hand knowledge to the English-speaking world. Christitch's transnational journalism was not limited to Britain. Her articles were reprinted in the United States and the British Empire, thus potentially reaching millions of readers. Moreover, newspapers around the world reported about her humanitarian work.

Second, this study argues that Christitch's war reports were written from a specifically feminine angle shaped by her war experience as a nurse and relief worker. The reports paid particular attention to the suffering of soldiers and civilians and to humanitarian aid provided in Serbia. They were not printed in the women's section, but appeared in the general pages of the Daily Express, together with other war news. Christitch's 'feminine' war accounts were consistent with the Daily Express' strategy of gendering the news. Adrian Bingham writes of the Daily Mail, the leading popular paper imitated by the Daily Express, that 'the re-orientation of news values allowed women and "women's interests" 
to enter the main body of the paper. Northcliffe [owner of the Daily Mail] sent bulletins to his news editors reminding them to "look out for feminine topics for the news columns". 25

The chronological structure of this study reflects the various stages of Christitch's journalistic and humanitarian engagement during the First World War. After a biographical sketch that highlights the transnational dimensions of Christitch's life and work, this article recounts Christitch's brief visit to the Western Front in November 1914, which was followed by a visit to Serbia from December 1914 to February 1915. In Serbia, Christitch witnessed the destruction and misery brought about by the war and a typhus epidemic. On her return, she published a series of eye-witness accounts and ran a fundraising campaign in the Daily Express. Moreover, she gave a series of lectures in Britain and Ireland to raise money and equipment for Serbian hospitals. In June 1915 she returned to Serbia with her mother, eight nurses and medical equipment. During the summer and autumn, Christitch managed relief operations in Valjevo, distributing medical stores and nursing typhus patients and wounded soldiers. She also published articles about her charitable work in the Daily Express. From October 1915 onwards she experienced the Austro-Hungarian occupation of Serbia. Although detained by the enemy, she was allowed to continue her humanitarian work until the spring of 1918, when she was finally able to return to England. During the occupation, Christitch was unable to publish in the British press. However, upon her return to London, she wrote a series of articles for British and American papers recounting her experience in occupied Serbia.

\section{Digitised sources and transnational history}

This study is based on an in-depth analysis of articles written by and about Christitch in the contemporary press of multiple countries. Lara Putnam argues that the transnational and digital turns in historical scholarship are closely intertwined. Digitised sources enable historians to study transnational phenomena and to conduct cross-border research without needing to physically visit archives in distant countries. Moreover, keyword searches in digitised archives make it possible to find relevant information without being an expert in the archival landscapes and historiographies of multiple countries. 'Digital search has become the unacknowledged handmaiden of transnational history', writes Putnam. 'For the first time, historians can find without knowing where to look. (... F)ulltext searchability has made seeking individuals, place names, phrases, titles, and organizations across hundreds of thousands of publications a viable way to trace international movement.'26 
Without keyword-searchable newspaper archives, the story of Christitch's transnational war reporting could not be told, for her writings were hidden in press archives in many different countries. I accessed the Daily Express, which published the bulk of Christitch's war reports, through the UKPressOnline database. The British Newspaper Archive provided access to a wide range of British titles. American and Canadian newspapers, as well as titles from India and Hong Kong, were accessed through ProQuest Historical Newspapers, Chronicling America, Newspapers.com and The Portal to Texas History. New Zealand and Australian papers were retrieved through Papers Past and Trove. ${ }^{27}$ Due to poor OCR quality, keyword searches often returned disappointing results. I therefore supplemented keyword searches by browsing day by day through many issues of the Daily Express and some American papers. In addition, I consulted unpublished documents from Christitch's personal papers in the John J. Burns Library at Boston College ${ }^{28}$ and from the National Archives in Kew, London.

\section{A life between nations}

Before investigating Christitch's war reporting, I will briefly sketch her transnational life. Annie Christitch was born in 1885 in Belgrade into a distinguished family. Her mother, Elizabeth O’Brien, was a well-known Irish writer, journalist, suffragist and advocate of Irish Home Rule ${ }^{29}$; her father, Colonel Ljubomir N. Christitch, was a Serbian officer and diplomat. Her grandfather, Nikola Christitch, was the first Prime Minister of the Kingdom of Serbia. Annie Christitch was brought up in Belgrade and St Petersburg, where her father held a diplomatic position at the Imperial Court of Russia, and she became fluent in several languages, including Serbian, English, Russian, French, German and Italian. In 1904, she moved to England to study at the University of London. While still a student, she joined the London Daily Express, initially reading the foreign press as an evening job. She remained on the staff of the Daily Express for more than a decade and won fame as one of the first female reporters to fly on an aeroplane. ${ }^{30}$

Little is known about Christitch's early journalistic work. The first articles that can be identified in the digital archive of the Daily Express date from the Balkan Wars. Upon the outbreak of the First Balkan War (October 1912 to May 1913), R.D. Blumenfeld sent Christitch as a war reporter to Serbia. Together with her mother and sister, she worked as a volunteer nurse in military hospitals in Belgrade until the end of the Second Balkan War (June to August 1913). ${ }^{31}$ Her reports in the Daily Express ${ }^{32}$ were reprinted in other newspapers in Britain ${ }^{33}$, in the British Empire and across the Atlantic. ${ }^{34}$ Sending out a woman as a war reporter was certainly unusual, but not unheard of in this period. 
During the Boer War (1899-1902), several British female journalists had reported from South Africa, among them Flora Shaw for The Times and Sarah Wilson for the Daily Mail. ${ }^{35}$ During the First World War, Christitch went to Serbia again as a correspondent and nurse. Although she fell into the hands of the Austro-Hungarian troops in the autumn of 1915, she was nevertheless allowed to organise food supplies for the starving population in occupied Belgrade with money received through neutral countries. In 1918 she returned to London. ${ }^{36}$

After the war, Christitch resumed her journalistic career. Occasionally, she wrote articles for the Daily Express. However, the exact scope of her collaboration with the newspaper remains obscure. Christitch also contributed to lay and Catholic newspapers and magazines in Britain, Europe and the United States, including the Daily Mail, The Times, The Tablet, Balkan Review, Nineteenth Century, The Fortnightly, The Contemporary Review (Britain), America, Ave Maria and The Catholic Advance (United States). ${ }^{37}$ In 1929 she published Women of the Gospel, a small volume with 'short meditations on the women who came in contact with our Lord in his early life, and their relation to modern womanhood.38

While England remained Christitch's chosen home for most of her life, during the interwar years she continued to campaign transnationally for the rights of English and Serbian women. Prior to the First World War she was instrumental in founding the women's movement in Serbia. She represented Serbia at the Fifth Congress of the International Woman Suffrage Alliance in London in $1909^{39}$ and again at the Eighth Congress in Geneva in June $1920 .{ }^{40}$ In England, she was a founding member of the Catholic Women's Suffrage Society in 1911, and she won international fame in May 1919 when she received the Pope’s blessing for the English women's franchise movement during a private audience given by Benedict XV. ${ }^{41}$ Christitch was in contact with women's suffrage movements throughout the world and attended all important women's conventions as a delegate and correspondent for British papers. In 1924 she was elected to the board of officers of the International Council of Women, acting as recording secretary. ${ }^{42}$

Starting in 1920, Christitch lectured extensively in the United States. She spoke on Serbia's hardships and recovery after the war; on international affairs, with special reference to Yugoslavia and Czechoslovakia; on the women's movement; and on Christian unity. ${ }^{43}$ The press in Britain, the British Empire and the United States reported regularly about her activism for the rights of Serbian and English women, as mentions of her in the digitised newspaper archives reveal. A photograph was taken of her by Bain News Service (Fig. 1), presumably during her lecture tour in the United States in the autumn of 1921, and subsequently appeared in American newspapers. ${ }^{44}$ 
TMG 24 (1/2) 2021

Stephanie Seul

\section{ANHIE CARSTITCH}

$5563-8$

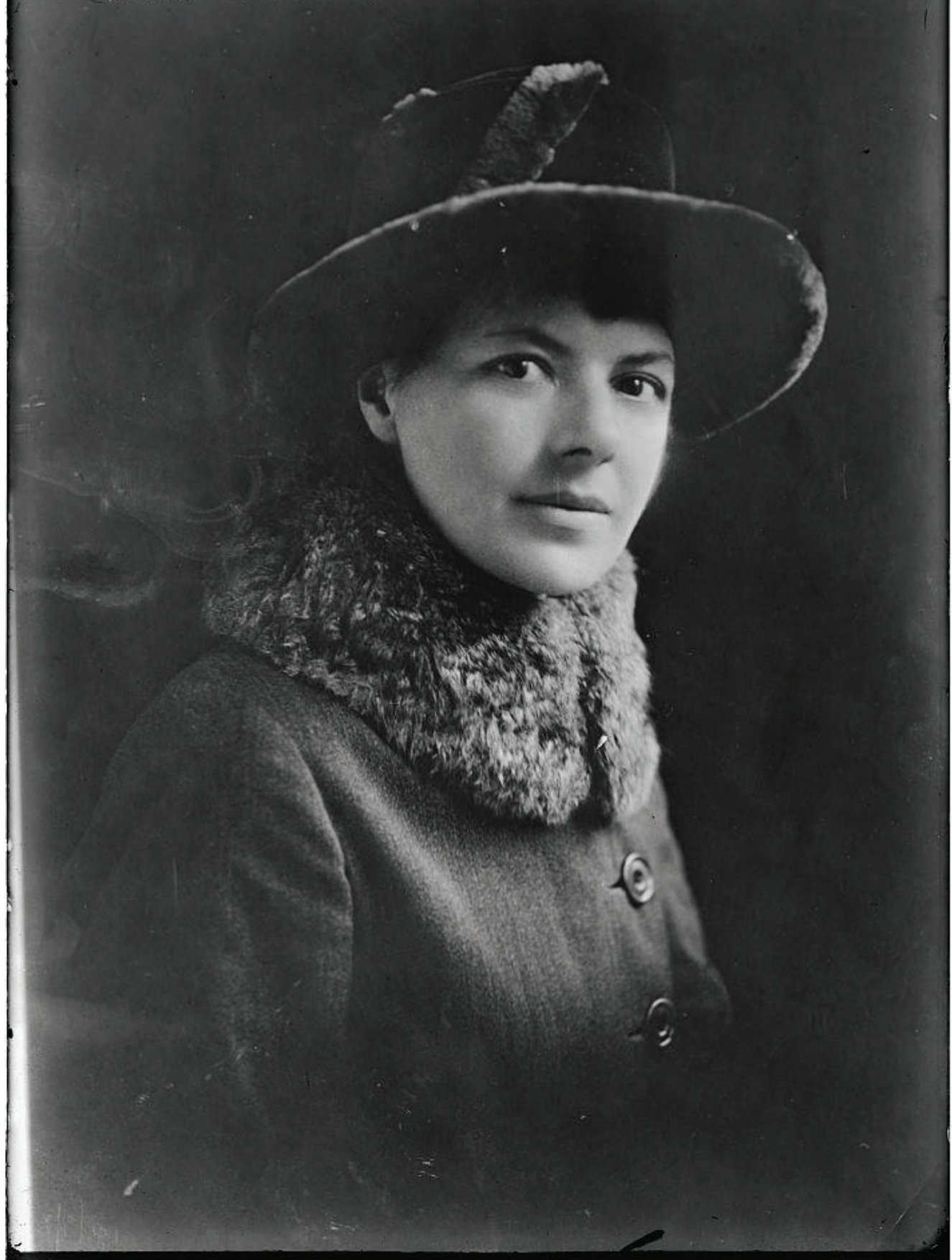

Figure 1. Annie Christitch, ca. 1920-1925, Bain News Service Photograph Collection, Library of Congress Prints and Photographs Division, Washington, D.C., https://www.loc.gov/pictures/item/2014713360/ (accessed July 10, 2020). 
During the interwar years, Christitch's transnational engagement extended beyond the women's movement. She campaigned for reconciliation between the Catholic and Orthodox Church in the newly-created Yugoslavia. Through her personal connections with President Tomáš Garrigue Masaryk, she worked towards an improved understanding between the Catholic Church and Czechoslovakia and for an understanding between Britain and Czechoslovakia. During the Second World War she helped allied soldiers escape from the Balkans and Czechoslovakia and supplied parcels to Yugoslav prisoners of war in Germany and Italy through the British Red Cross. ${ }^{45}$

In her lifetime Christitch received many decorations and orders, among them The Order of St Sava, awarded by the Kingdom of Serbia for her literary work. For her charitable work during the First World War she was awarded the highest order of the Serbian Red Cross, the Serbian Supreme Command's official commendation for services to army and nation, and the Order of the Serbian White Eagle. In 1934 she received the Czechoslovak Order of the White Lion in recognition of her efforts toward a rapprochement between Britain and Czechoslovakia. ${ }^{46}$ After having lived in London for decades, Christitch was naturalised as a British citizen in 1950. ${ }^{47}$ She died in Bath in 1977 at the age of 92. British newspapers reported her death; The Times and the Catholic magazine The Tablet, among others, published obituaries. ${ }^{48}$

This biographical sketch gives an idea of the transnational connections in Christitch's private life and her professional career as a journalist, lecturer and Catholic suffragist. The following narrative will proceed chronologically through Christitch's war journalism and charitable work in Serbia. As a Serbian national on good terms with local authorities and as a staff member of the Daily Express who was fluent in English, she was ideally positioned to communicate first-hand knowledge of wartime Serbia to an English-speaking audience.

\section{On the Western Front, November 1914}

Except for a brief visit to the Western Front in November 1914, Christitch spent most of the First World War in Serbia, acting as a war correspondent, nurse and relief worker. She published more than 30 war reports in the Daily Express. Some articles appeared in The Tablet, the Church League for Women's Suffrage and the Belfast Telegraph. A long article was distributed through the Edward Marshall Syndicate in several American publications. 
Little is known about Christitch's journalistic work during the first months of the war. In September 1914, she used the letters to the editor section of the Daily Express to express her views about the war, calling for due public recognition of Serbia's heroic fighting. ${ }^{49}$ In midNovember, she visited the Allied frontline in Belgium as a special correspondent for the Daily Express and was, according to an international woman suffrage publication, the first woman journalist to come under fire. ${ }^{50}$ On her return to London, she published three articles in the Daily Express under the signature 'A. Christitch'. The first, a long front-page piece on November 19, recounted her visit to the bombarded and deserted town of Nieuport (Nieuwpoort) in West Flanders. This area was held by the Allies. ${ }^{51}$ 'Clean, industrious, coquettish little Nieuport, as we had known it in happier days had become an abomination of desolation', she wrote. 'Facing us stood the once beautiful church with its roof torn off and its walls riven. We had a glimpse of a shattered altar through the clefts as we hurried through the shell-ploughed streets, picking our way among stones, earth-mounds, pieces of shrapnel and sinister-looking cavities - sites of recent explosions. (...) In silent depression we went on. ${ }^{52}$ In Nieuport, Christitch and an unnamed woman accompanying her experienced the shelling of the town by German artillery. 'Beyond the canal, in the open space in front of us, we saw fiery globes wafted on dense clouds of smoke towards the French trenches, and their buzz through the air sounded more fiendish to our ears than even the thunder of the firing.' As the firing became more intense, the women sought shelter but could find no protection. Christitch concluded: 'It was folly to proceed, especially as our destination was remote, and lay in the direction of the harbour, so much coveted by the enemy. We regained our car sadder and wiser as to the conditions of war., 53

While on the Western Front, Christitch also visited Belgian and French military hospitals. In her second story, published on November 20, she paid tribute to the Belgian nurses: 'Visiting the different hospitals near the front a few days ago, another woman and myself were deeply impressed by the care and devotion bestowed on the German wounded who were lying in the French and Belgian hospitals', she wrote. 'We were particularly struck by the tender solicitude of the Belgian women, which extended to the mental as well as the physical condition of their patients. (...) Nearly all the patients whom we saw were unanimous in their gratitude for the care with which they were tended.54

Christitch's third article, printed on November 21, was devoted to the 400 British nurses attached to the British Expeditionary Force in France, who were working in appalling circumstances. She wrote: 
Having just returned from France I may state that the excessive demands made on the pluck and endurance of the nurses are met with a devotion second only to the valour of the men in the firing line. Trained skill, mental fortitude, and physical endurance are taxed to the utmost by the appalling cases with which the nurses must deal. Regular hours of rest are denied them, and the few brief moments of respite are spent in chill, comfortless surroundings. In some of the emergency hospitals in France where the nurses are working I saw with consternation that the very essentials for ordinary wellbeing were totally lacking. (...) Risks of infection are great, especially of such terrible diseases as tetanus, but the British nurse neither shirks nor shrinks. ${ }^{55}$

Christitch appealed to readers to donate money to a Daily Express fund that had been established to raise money for Christmas gifts for the British nurses in France. Between November 19 and December 2 the Daily Express printed almost daily short articles on the British nurses, and on December 3 it announced: "Thanks to the generosity of "Daily Express” readers a sufficient sum of money has been collected to provide a Christmas gift for each of the British nurses at the front. ${ }^{56}$

Christitch's accounts of her visit to the Western Front were reprinted with different headlines in the United States and the British Dominions. For instance, in December 1914 her article 'Impressions of a Woman Under Fire at the Front' appeared in the American papers The Fort Wayne Daily News (Indiana), the El Paso Herald (Texas), the Journal Gazette (Mattoon, Illinois) and The Washington Herald (District of Columbia). In Canada, Christitch's impressions of Nieuport were reprinted by The Citizen (Ottawa, Ontario) and the Victoria Daily Times (British Columbia), and in mid-January 1915 they also appeared in Australian papers, including the Darling Downs Gazette of Queensland. ${ }^{57}$ Almost two months after it appeared in the Daily Express, Australian papers also reprinted Christitch's article on the work of British nurses in France, 'Heroines of the Nursing Line'.58

\section{Visit to Serbia, December 1914 - February 1915}

Shortly after her return from Belgium and France, Christitch decided to travel to Serbia to help her struggling native country. In the first months of the war, Austria-Hungary attacked Serbia three times, committing atrocities against Serbian civilians and causing heavy casualties on both sides. During the third offensive, which started on November 6, 1914, Belgrade was temporarily occupied, 
but was eventually liberated by the Serbian army on December 15. Due to the intense fighting and heavy losses, neither side was able to continue with offensive action. ${ }^{59}$ During the winter of 1914-1915 a typhus epidemic broke out, causing severe losses among Serbian soldiers and civilians and the 70,000 Austro-Hungarian prisoners of war. Serbia, exhausted from the Balkan Wars of 1912-1913 and lacking doctors and nurses, was unable to deal with the large number of wounded. Allied and neutral countries therefore sent medical missions to Serbia to help reduce the hardship. ${ }^{60}$ Britain sent medical missions provided by the Serbian Relief Fund, the Red Cross and the Scottish Women's Hospitals for Foreign Service. The latter was founded by the Scottish physician, surgeon and suffragist Dr Elsie Inglis in 1914 with the financial support of the National Union of Women's Suffrage Societies. The American Red Cross sent six hospital units to Serbia staffed entirely by women. ${ }^{61}$ The first unit, under Dr Eleanor Soltau, arrived in Serbia in December 1914 and set up a hospital in Kragujevatz, a key Serbian army base, where one-tenth of all typhus cases in the country were counted. ${ }^{62}$

Christitch left for Serbia in December 1914, travelling via the British colony and naval base Malta and Salonika (Thessaloniki) in neutral Greece. ${ }^{63}$ With her travelled a group of British nurses, to whom Christitch taught the basics of the Serbian language necessary for their work in Serbian hospitals. ${ }^{64}$ From Malta she dispatched an article that appeared in the Daily Express on January 14, 1915. It described in an easy, conversational tone the everyday life on an island seemingly not yet affected by the war: 'At first sight there are few indications in Malta of the great world war', she wrote. 'The well-lighted streets are in marked contrast to those one has left behind in London, and the pavement is crowded between six and eight o'clock in the evenings, when every one meets every one else on the corso. ${ }^{65}$ This article was reprinted ten weeks later in New Zealand. 66

Upon her arrival in Serbia in late December 1914, Christitch took up work as a war correspondent and interpreter for Dr Soltau's Scottish Women's Hospitals unit in Kragujevatz, and she also taught Serbian to British nurses. ${ }^{67}$ According to a contemporary press report, she was herself closely involved in finding quarters in Kragujevatz for the unit. ${ }^{68}$ During the following two months she visited several cities, among them Nish, the wartime seat of the Serbian government; the capital Belgrade; and Valjevo, the town hit hardest by the typhus epidemic. After her return to London in early March 1915, she published a series of articles in the Daily Express recounting her experiences. The first, published on March 4 and reprinted in New Zealand, was written in a patriotic tone. It described the presence of thousands of Austro-Hungarian prisoners of war who were enjoying 
liberty and the hospitality of the Serbian people. 'It is startling to arrive in a country which has just repelled the invader and to be confronted at every turn by the uniform of the enemy', she wrote. 'Servia ${ }^{69}$ has neither gaols nor guards for the overwhelming number of war captives that fell to her share. She treats them, therefore, as uninvited guests, towards whom the usual forms of hospitality must be maintained at all costs. ${ }^{70}$

During a visit to Belgrade, Christitch witnessed the destruction brought about by AustroHungarian artillery: 'Many of the buildings have been charred and demolished - black streaks disfigure the river walls - yet the Servian capital continues to stand dauntless, proud, and menacing on the banks of the two rivers which separate it from the enemy's territory.' The Austrians, Christitch wrote, 'have shown a wanton spirit of destruction by the manner in which they used our capital. What they were unable to carry off they damaged. (...) Of the many Austrian retreats from Belgrade the last one has been the most undignified. ${ }^{71}$ The article was reprinted in the Evening Telegraph and Post of Dundee, Scotland, on March 8; in the South China Morning Post in the British colony Hong-Kong on April 23; and in three New Zealand papers in May. ${ }^{72}$

While in Serbia, Christitch visited several hospitals in Nish, Uskub (Skopje), Ghevgeli (Gevgelija) and Kragujevatz. ${ }^{73}$ However, it was the typhus-stricken town of Valjevo that left the deepest impression on her. Valjevo, located on the north-western frontier of Serbia, had borne the brunt of the Austro-Hungarian attacks. After the enemy's retreat, typhus spread rapidly, leading to a high death toll among the Serbian population and the Austro-Hungarian prisoners of war. Christitch arrived in Valjevo in February 1915 at the height of the epidemic. ${ }^{74}$ 'On my arrival I saw a number of stretcher-bearers silently ploughing their way with their burden through the mud that lay ankle deep over what had once been an excellent pavement', she wrote on March 5:

Men in uniform lay on the stretchers, and I approached one of them to inquire after his injuries. The glassy stare and rigid limbs told their own tale. He was dead. The rapidity with which the victims are mown down by fever makes it impossible to provide coffins, even if the wood were obtainable. (...) The most onerous task here is that of removing the dead as rapidly as possible.

Upon their retreat, the Austrians had left 3,000 sick and wounded soldiers behind, making Valjevo the centre of the typhus epidemic. Everything was lacking in the town: hospitals, doctors, nurses, beds 
and linen. The sick lay on bare floors in their uniforms. 'Some buildings, of course, have regular wards and beds, but others are merely the ante-chambers of the grave. Men are brought here to die under cover. (...) The men are doomed.' A Serbian military surgeon called on Christitch to send expert fever nurses and basic supplies such as beds and body linen to help fight the epidemic. ${ }^{75}$ The article "The ‘Liberation' of Valjevo” of March 5 was reprinted in many Australian and New Zealand papers in April and May 1915.76

\section{Raising funds for typhus-stricken Valjevo, March-May 1915}

Christitch offered her nursing services to hospitals in Valjevo, but it was impossible to alleviate the suffering without an adequate supply of linen. ${ }^{77}$ In early March she therefore returned to London 'to collect a few sheets and shirts for this most distressed region'. ${ }^{78}$ In the letters to the editor section of the Daily Express, she announced the setting up of a relief fund for Valjevo and appealed to her readers to donate bedding, medical equipment and money. ${ }^{79}$ Serbia had over 40,000 sick and wounded and was unable to cope with the burden, she wrote on March 11:

At Valjevo, which has borne the brunt of two invasions, men are dying in agony without even a pillow under their heads. A small group of fever nurses with a supply of clothing, medical stores, etc., would retrieve the situation. If your readers will help me with gifts of blankets, sheets, shirts, pyjamas, stores, etc., I will find the skilled workers (...). ${ }^{80}$

Her appeals bore fruit. On March 23 she expressed her appreciation for the generous contributions to the Valjevo fund and for parcels of clothing and medical stores that had reached her from all parts of Britain, amounting to equipment for 100 beds. At the beginning of April she was able to send off $£ 100$ and a consignment of sheets and shirts to Valjevo. As her help was not needed in Valjevo, Christitch decided to remain in London and continued to raise funds through the 'Daily Express Valjevo Fund'. ${ }^{81}$ The Daily Express supported Christitch's appeal. From March 24 onwards, several times a week it published short notices about the campaign and its progress, listing the donors and their contributions and providing an address where parcels of clothing and other necessities could be sent. The money was collected through the Serbian Relief Fund. ${ }^{82}$ Under the headline 'Daily Express Valjevo Fund', the Daily Express printed notices about the appeal until February 24, 1916, at which 
point Christitch's mission had already left Valjevo due to the invasion of Serbia by Austro-Hungarian, German and Bulgarian troops. ${ }^{83}$

Parallel to her journalism and fundraising campaign in the Daily Express, from March to May 1915 Christitch undertook several lecture tours through England, Scotland and Ireland to inform the British public about Serbia's plight and to raise money for Serbian hospitals. Her tours can be traced in the British Newspaper Archive. Christitch spoke on several occasions in London ${ }^{84}$ and lectured in Leeds, Sevenoaks, Hayward Heath and other towns. ${ }^{85}$ In mid-April she went to Ireland and spoke in Londonderry, ${ }^{86}$ and her two trips in Scotland - one week-long trip in mid-March, as well as a shorter tour in early May - took her to Perth, Dundee, Edinburgh and Falkirk. ${ }^{87}$ The venues where she spoke ranged from churches, theatres and town halls to gymnasiums and hotels. Several of her lectures - which, according to contemporary press accounts, drew large audiences and were highly lauded - were illustrated with lantern slides. The Tablet commented on her lecture in the Cathedral Hall in London on April 28, 1915, held under the auspices of the Catholic Association and presided over by the Archbishop of Westminster: 'Excellent slides were thrown on the screen illustrative of the lecture. ${ }^{88}$

Christitch's lectures were widely promoted and reported on in the local press and she was praised as a gifted speaker. She spoke on March 22 and again on May 1-2 in the Scottish town of Falkirk. Ahead of her second visit, Falkirk's local newspaper lauded her in the highest terms, highlighting her role as a cultural mediator between Serbia and Britain:

Miss Christitch, the speaker who is to present the case for Serbia this (Saturday) evening in St Andrew's Church, Falkirk, is one of the few Serbians who have chosen journalism for a profession. Attached to the staff of the "Daily Express", she has proved herself to be possessed of strong literary gifts, and although a Serbian of the Serbians, writes charmingly in an excellent English style. (...) In her burning desire to help [Serbia], Miss Christitch has almost deserted the desk for the pulpit and the platform, and in the opinion of many has won even greater triumphs in the new sphere than in the old. Her simple, earnest, unaffected, unadorned style of speaking is most effective (...). Hers is no carried tale. She speaks only of what she knows and has seen, and in listening to her as she depicts in vivid and telling phrase the scenes she has witnessed, one feels that she has the supreme gift of conveying the atmosphere of the land for which she pleads, and in bridging for her audience the great gulf that separates us from her people, preventing us from understanding their wants and rendering them the assistance they so greatly need. ${ }^{89}$ 
In her lectures, which mirrored her written accounts in the Daily Express, Christitch sought to arouse the sympathies of her British audience for Serbia by reporting on the humanitarian side of the war - the devastation brought about by the Austrian invaders, the large number of wounded, and the typhus epidemic raging among the 70,000 Austrian prisoners of war and Serbian civilians alike. This story was embedded in a patriotic explanation of the political and military developments in her native country since the outbreak of war, thus familiarising the British public with the little-known history of Serbia, Britain's smallest ally. So graphic were her accounts of the situation in Serbia that, according to the Yorkshire Post, 'Many people present had to leave because they could not stand the recital of the horrible state of things. ${ }^{90}$ Still, the lectures were a great success, not only because Christitch was considered a credible eyewitness, but also because she was held to belong to Britain as much as to Serbia due to her Irish descent. ${ }^{11}$ Christitch concluded all her talks with urgent appeals for money, clothing and linen; collections were taken to aid the Valjevo district, which, according to contemporary press reports, resulted in generous donations. $^{92}$

Newspapers in the British Empire also reported on Christitch's lectures. On May 23 The Times of India published a summary of a lecture Christitch had given under the auspices of the Serbian Relief Fund in London, ${ }^{93}$ and the Catholic Press of Sydney in Australia reported on her lecture in the Cathedral Hall in London on April 28, which was presided over by the Archbishop of Westminster. ${ }^{94}$

\section{Nurse, relief worker and war reporter in Valjevo, June-October 1915}

With the funds raised through her appeals in the Daily Express and lectures and with grants of money from the Serbian Relief Fund and the London section of the Serbian Red Cross, Christitch put together her 'Valjevo Relief Party' (also called the ‘Christitch Mission' or 'Christitch Unit'). It consisted of herself, her mother, eight nurses and a large quantity of hospital equipment and medical supplies. The group had the approval of the British War Office, the Foreign Secretary Sir Edward Grey and the Serbian Minister in London. The Valjevo Relief Party left London on May 24, 1915, and Christitch promised to write from Serbia to give the readers of the Daily Express detailed accounts of her work..$^{95}$ The party travelled via Paris, Marseille, Malta, Athens and Salonika. The first two reports were dispatched from Marseilles and Salonika on May 27 and June 4 and published several days later. They described Christitch's impressions of wartime France and neutral Greece. ${ }^{96}$ 
Immediately upon her arrival in Valjevo, Christitch began to distribute her supplies to patients. 'Neither the fatigues nor the perils of the journey to Serbia can weigh for one moment in the balance against the joy of to-day's distribution of “Daily Express” gifts through the hospital wards of Valjevo', she wrote in the Daily Express of July 8, 1915. 'For the present my chief occupation consists in doling out hospital requisites for needy patients. No man need any longer lie on the floor in Valjevo (...) The "Daily Express" nurses have already done splendid work in Valjevo, and they are making the typhus patients as comfortable as possible. ${ }^{97}$ The military authorities put a large storehouse at Christitch's disposal for her supplies as well as a staff consisting of a secretary, two gendarmes, two orderlies, and three teams of oxen to transport her supplies. She concluded: 'Thanks to the bales of clothing which I have been given, our relief party is able to cope with much of the distress (...). ${ }^{98}$

During the summer and autumn, Christitch managed relief operations in Valjevo, distributing hospital equipment and nursing typhus patients and wounded soldiers. Unlike other British hospital units working in Serbia, the 'Christitch Unit' did not have its own doctors and equipment or operate a hospital. Instead, the nurses and equipment of the 'Christitch Unit' were divided among military hospitals established by the Serbians. ${ }^{99}$ Overall, Christitch fully equipped and reorganised eight hospitals, each under the supervision of a British nurse. ${ }^{100}$ Sybil Eden, an English Red Cross nurse working in Serbia, described Christitch's achievements in December 1915 in the Daily Express:

There were eight hospitals in the town under Miss Christitch's superintendence, and their cleanliness and general equipment were really remarkable, considering all the circumstances. Miss Christitch visited all the hospitals every day, and on Sundays she distributed chocolate and tobacco to all the wounded. She was regarded as a queen, and was worshipped by everybody. ${ }^{101}$

Christitch's other charitable work included a sewing class for Serbian girls and boys. On September 23 she reported: 'With schoolmasters gone to the front, schoolmistresses nursing in hospital or dead of typhus, and the buildings themselves commandeered for various purposes, the youngsters had been left very much to themselves. Their raggedness and superfluous leisure inspired me with the idea of mobilising them into a self-clothing organisation.' With Christitch, the boys and girls made bed-bags for the hospitals: 'Thus, in working for the sick and wounded and for each other, the children forget the past and live in the present, never wasting a thought on what the future 
may have in store for this exposed frontier. ${ }^{102}$ On the same day that this report appeared, the Daily Express published a photograph of the Christitch Unit (Fig. 2). Christitch is seated in the middle, surrounded by five of her nurses and holding a copy of the Daily Express in her hands. The photograph symbolises both the financial relationship between the 'Christitch Unit' and the Daily Express - the mission was maintained by the 'Daily Express Valjevo Fund' - and the dual role of Christitch as a relief worker and Daily Express correspondent in wartime Serbia.

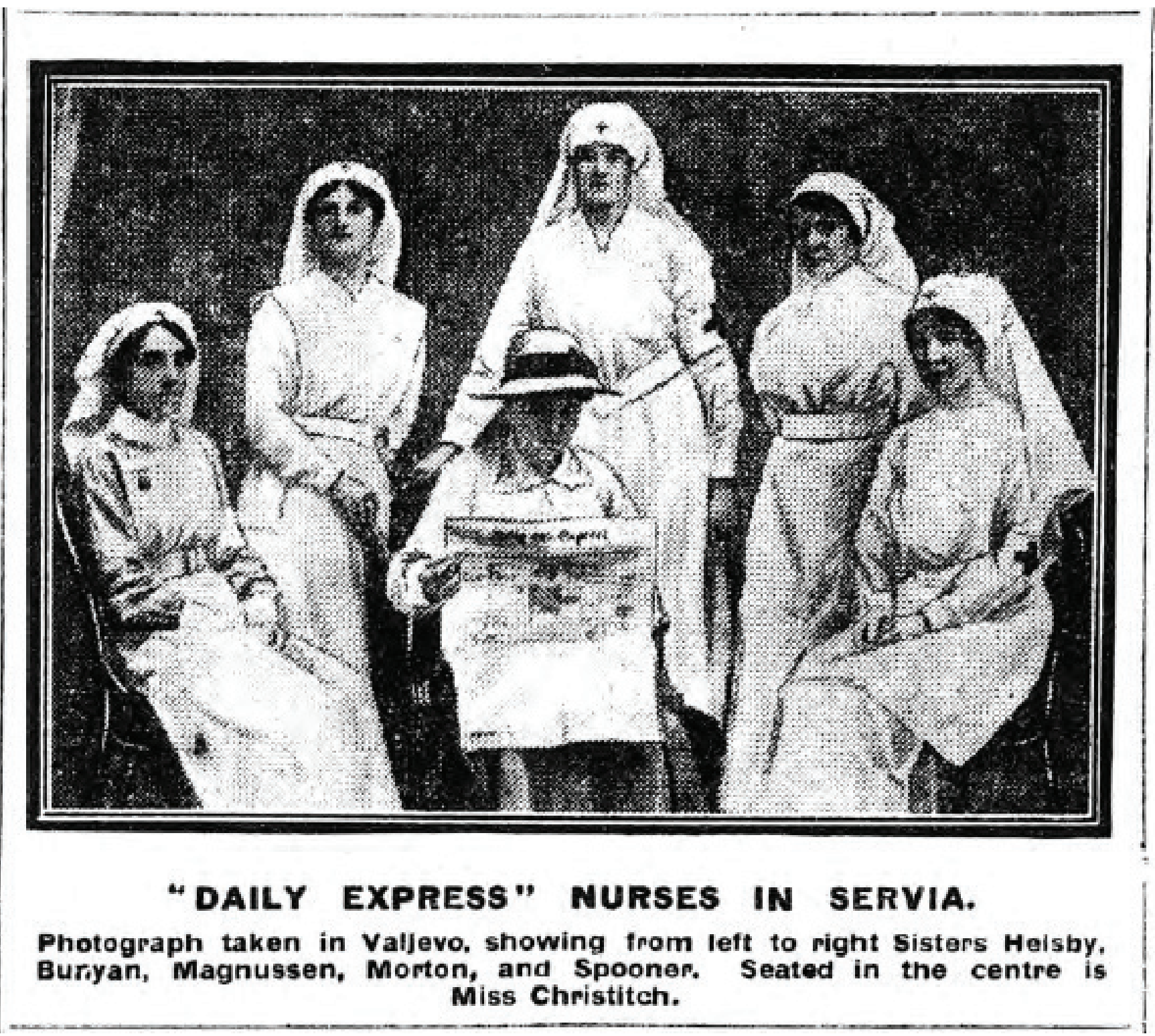

Figure 2. Daily Express, September 23, 1915, 6. 
Christitch's last report from Serbia was written on September 22 from Vishegrad. It appeared in the Daily Express a month later and was reprinted in the Oamaru Mail in New Zealand on December 7. At the request of Sir Ralph Paget, the British Commissioner for the coordination of relief work in Serbia, Christitch had travelled to Vishegrad, which was partially occupied by the Austrians, to conduct a relief expedition for the benefit of the war victims. She described her visit, during a lull in the fighting, to the destroyed and pillaged Bosnian town, in plain sight of the Austro-Hungarian troops on the other side of the river, as well as her visit to refugee camps on the hills a few miles outside Vishegrad:

We found [the war victims] housed in wooden huts scattered far and wide on this side of the river. These shelters were erected over the heads of refugees too sick with fever to proceed any farther. We made our brief quarters at Dobran, and pitched a camp for the distribution of food and medical stores. This ruined village is well out of reach of the enemy's fire, and is within walking distance for 600 families scattered on the mountain side. (...) Ragged, gaunt, and diseased, they come to us now for anything we can give. ${ }^{103}$

\section{Experiencing the Austro-Hungarian occupation, October 1915 - spring 1918}

When Christitch's article was published on October 22, Austro-Hungarian, German and Bulgarian armies were invading Serbia from the north and east. The campaign, which lasted for seven weeks, overwhelmed the Serbian army, which suffered from a lack of supplies, including ammunition. Followed by thousands of refugees, the Serbian army withdrew across the mountains of Albania and Montenegro towards the Adriatic Sea. During their epic retreat, the Serbians suffered heavy losses from cold, hunger, diseases, and Albanian attacks. Eventually, the remnants of the Serbian army took refuge on the Greek island of Corfu. Meanwhile, Austro-Hungarian and Bulgarian troops occupied Serbia and imposed a harsh regime on the civilian population. ${ }^{104}$

When hostilities had broken out on October 6, Christitch's hospitals had begun to nurse large numbers of wounded Serbian soldiers. However, as the front drew nearer, the Serbian army ordered the evacuation of Valjevo. The 'Christitch Unit' left on October 19 with the last train and accompanied the Serbian army on its retreat, taking its medical supplies with it. ${ }^{105}$ At the beginning of November, Christitch decided to remain behind in the town of Trstenik, since her mother was unable to face the hardships of a mid-winter march through the mountains. Moreover, large 
numbers of heavily wounded and abandoned soldiers needed urgent care, and Christitch had the materials to clothe, bed, feed and heal them. She therefore preferred to remain where her help was needed. With her remained the Norwegian nurse Miss Magnussen (whose first name remains unknown), while the other British nurses of the unit retreated with the Serbian army through the mountains. Trstenik later fell into the hands of the Austro-Hungarians, and Christitch and her mother were taken prisoner. As the British press reported, they were well treated and allowed to move around freely and continue their hospital work. ${ }^{106}$ However, while in occupied Serbia, Christitch was unable to publish her reports in the British press. It was only after the Austrians allowed her and her mother to leave Serbia, in the spring of 1918, that she began to publish a series of articles in the Daily Express and other papers. The following account of her experiences in Serbia from 1916 to 1918 is based on these reports.

Christitch, her mother and Miss Magnussen remained in Trstenik during the winter of 1915, nursing wounded Serbians in a private hospital that they had set up on their own initiative and nursing typhus patients in a separate hospital for infectious diseases. They enjoyed immunity from Austrian interference. However, in the spring of 1916, they were asked to move to a hospital in Rushka to nurse wounded Serbians. This would have meant falling under the authority of the Austrians. Christitch therefore declined collaboration and disbanded her hospitals. Miss Magnussen departed for Norway, while Christitch and her mother moved to Belgrade in March 1916, hoping that they would be able to return to England from there. Yet no Serbian national was allowed to leave the country, so the women remained in Belgrade for over two years. ${ }^{107}$

In Belgrade, Christitch was confronted with the horrors of a civil population on the brink of starvation. 'There was an epidemic of suicide among the refugees who returned to their shellshattered and ransacked homes', she wrote. 'No banks were left, and the richest families were destitute and ragged. ${ }^{\prime 108}$ In August 1916, the American Red Cross asked Christitch to organise a soup kitchen to feed the poor. She was able to provide food for 1,200 people a week until Christmas 1916, when the Americans left Belgrade. Christitch, her mother and a group of volunteers then continued the soup kitchen and other relief work with the help of fresh money from Britain. The crowds waiting for help outside her office in the ground-floor library of her father's house in Belgrade were large enough to arouse the suspicion of an Austrian gendarme; she 'always managed to persuade him, however, that all was in order and that [she] was making lists of poor for the possible arrival of food stuffs and clothes from Switzerland. ${ }^{109}$ 
Thanks to the intervention of influential English friends, in the spring of 1918 the Austrians finally allowed Christitch and her mother to leave Serbia. Travelling via Vienna and Innsbruck, Christitch reached Zurich in mid-June, where she remained for several weeks to recover. ${ }^{110}$ From Zurich, she dispatched two articles to the Daily Express. The first, published on June 26 and reprinted in three Australian papers in September, praised in a patriotic tone the unbroken spirit of the Serbian people under Austrian occupation. 'I have just come here after two and a half years under the yoke, and can only tell of the splendid spirit of the Serbian nation, its unflagging trust in England and England's triumph, its stubborn resistance under loneliness and privations', she wrote. 'Serbia is undaunted as Great Britain is invincible.'111 Her second article, on July 1, recounted her hospital and relief work in Trstenik and Belgrade under Austro-Hungarian occupation. It was reprinted in three newspapers in New Zealand. ${ }^{112}$ Meanwhile, the Daily Express lauded its staff member: 'Everyone who knows her hopes that Miss Annie Christitch, the "Queen of Valjevo", will soon come back to England to resume her work for the "Daily Express". (...) She is a first-rate journalist and a fine speaker."113

After two months of recuperation in Switzerland, Christitch returned to London in September 1918 and resumed her journalistic work. ${ }^{114}$ Over the following three months, she published a series of articles in the Daily Express and other British and American publications recounting the desperate situation in occupied Belgrade and her relief work. She appealed to her readers to send fresh supplies, especially boots and clothes for Serbian children: 'The coming winter will sound the death-knell of thousands of children in fettered Serbia. Facts must be faced. The population of Serbia is dwindling daily, carried off by disease and privation', she wrote on September 30.115 A day later, she portrayed her Belgrade home 'wrecked by the Huns': 'The hall was littered with papers, remnants of broken chairs, and other debris, but this was only a mild intimation of what awaited us in the rooms. (...) Things had been flung about out of pure devilry, for as we afterwards learned, four Germans had resided in the house for many weeks.' ${ }^{116}$ In another article she described the brutal policy of denationalisation enforced by the Bulgarians in their zone of occupation: Under threat of penalty, Serbs were forbidden to speak their language and were forced to change their Serbian surnames into Bulgarian ones, and children were forced to read, write and recite in Bulgarian. But their national spirit remained unbroken, as Christitch underlined. ${ }^{117}$

Christitch also emphasised that many Serbian mothers tried to smuggle a bag of flour for their children because the rations of flour allocated by the Austro-Hungarians were far from sufficient. Several women were wounded or shot by sentries guarding the roads. Others ruined their health by 
wading through streams or hiding in hedges under the rain and snow. ${ }^{118}$ Cut off from their breadwinners, women of all social ranks had to take whatever work they could find: 'Thus one saw women in furs or smart tailor-mades - the remnants of former days - trundling wheelbarrows of stone for road repairs, or carrying heavy loads. Another most repugnant but remunerative occupation was work at the slaughterhouse'. Christitch affirmed: 'The courage of the women of Serbia under the enemy ranks with the valour of her men in the field. ${ }^{119}$ Her last contributions in the Daily Express in December 1918 were two lighter pieces in the women's pages dealing with wartime wear made of sheets and with the difficulty of baking bread while lacking basic ingredients. ${ }^{120}$

In November, Christitch recounted her long journey from Belgrade to London 'through occupied, enemy, neutral and Allied countries' in the Catholic weekly magazine The Tablet. In faminestricken Vienna, where Christitch and her mother were held for a week as enemy aliens, 'everything [.] gave the impression of sorrow and suffering'. Other stops in Austria included Innsbruck and the Arlberg. After two months in Zurich, they continued their journey through Fribourg, Geneva and Paris until they reached London. ${ }^{121}$ Finally, Christitch published a long account of her relief work in Trstenik and Belgrade under Austrian occupation in the Belfast Telegraph and several American newspapers. These articles were distributed in late November and early December through the Edward Marshall Syndicate, a leading war feature service with headquarters in London and branches in Paris, Petrograd and Rome. Headed by Edward Marshall, an internationally known war correspondent, the service furnished news stories and interviews from the different fighting fronts in Europe, mainly to leading American newspapers. ${ }^{122}$ While the story told by Christitch remained the same in all articles, the newspapers added different headlines and biographical notes. ${ }^{123}$

After 1918, Christitch's war reporting did not fall into oblivion. Every now and then papers in Britain and abroad recalled her role during the First World War. The monthly organ of the International Woman Suffrage Alliance wrote that Christitch went to Belgium in 1914 as a special correspondent of a London daily 'and was the first woman journalist to receive her baptism of fire.'124 The New Zealand Tablet, reporting on her lecture tour in the United States, recorded her work as a war correspondent in Belgium and Serbia and her ensuing confinement by the enemy. ${ }^{125}$ In the United States, the St. Louis Star of Missouri reported that, during the war, 'Miss Annie Christitch of Belgrade (...) did correspondence work for several London papers.' ${ }^{126}$ And finally, The Tablet's obituary of Christitch mentioned her work in Serbia as a correspondent and interpreter for a Scottish Women's Hospitals unit. ${ }^{127}$ 


\section{Conclusion}

During the First World War, Christitch was not the only woman to report from the front for British newspapers. Rather was she part of a growing profession of female journalists who undertook press work during the war. It is difficult to establish the exact number of female war reporters for lack of research literature, but several women stand out. The American Avice Waterman, a London Times' correspondent in Milan, and Mary Frances Billington, a staff journalist working for the Daily Telegraph, were mentioned earlier, as was Alice Askew, Evelyn Ross and Hilda M. Love, who all published war-related articles in the Daily Express. Alice Askew and Hilda M. Love also wrote for the Daily Mail. This popular mass-circulation paper commissioned several other women to report on the war, among them Olive Dent, F. Tennyson Jesse, and the Australian Louise Mack. Their articles can be traced in the digitised newspaper archives. ${ }^{128}$ War reports were also written by May Sinclair, Bertha Bennett Burleigh, Vera Collum and Marie Harrison for British and American newspapers and magazines. ${ }^{129}$

However, among the women who reported from the theatres of war in different roles for British publications, Annie Christitch stands out as a correspondent whose life and career transcended national boundaries. She was of Irish-Serbian descent, was multilingual, was educated in several countries, and lived and worked in London and Serbia. She travelled and lectured internationally; was actively involved in the Serbian, English and international women's movements; and her writings were published in newspapers and journals around the world. Her transnational biography made Christitch a perfect go-between for different nations and cultures. As a Serbian national fluent in English and as a staff member of a mass-circulation London daily, she was ideally positioned to communicate her first-hand knowledge of wartime Serbia to the English-speaking world. Christitch had intimate knowledge of Serbian history and customs and she was on good terms with local authorities and military leaders who supported her hospital and relief work.

Christitch’s transnational journalism was not confined to Britain. Her articles were reprinted and read on other continents as well, thus potentially reaching an English-speaking audience of millions of readers around the world with reports on war conditions in Serbia. Her long report of November 1918 was circulated on the British Isles and in the United States by newspapers subscribing to the Edward Marshall Syndicate, and her writings in the Daily Express were distributed in Australia, New Zealand, Canada and Hong Kong, albeit with a time lag of 
several weeks. As Simon Potter has shown, in the late nineteenth and early twentieth centuries the exchange of news and information played a significant role in promoting transnational connections between the different parts of the British Empire. This exchange was greatly facilitated by international news agencies and communication technologies such as telegraphs and submarine cables. ${ }^{130}$

As a woman journalist reporting across geographic and cultural borders during the First World War, Christitch was not a unique phenomenon. Other examples include Sofía Casanova, Alice Schalek and Thea von Puttkamer. However, the conventional national perspective in journalism history does not do justice to these women. If we study the press of only one country, we may miss out on female war reporters who published in other countries. For practical reasons, the study of transnational female war reporting depends on the digitisation of newspaper archives, which allows for the cross-country examination of a large number of publications. Thus, the story of Christitch's transnational war reportage could not have been told without keyword-searchable databases, for her writings were hidden in press archives on three different continents.

Christitch's war reportage from Serbia was shaped by her gender-specific war experience. As a nurse and relief worker, she nursed, fed and clothed sick and wounded soldiers and civilians in Valjevo, Belgrade and elsewhere. Moreover, as a Catholic women's activist, she displayed a special interest in the fate of Serbian women and their families. Christitch's focus on the humanitarian side of the war was consistent with much of the female war reporting during the First World War because a large share of war news was written by nurses working in military hospitals and experiencing the impact of industrialised warfare. ${ }^{131}$ Although Christitch's war reports had a feminine touch, they were not treated by the Daily Express as purely 'women's stuff'. Except for two lighter stories in December 1918, which were printed in the women's section of the paper, all her accounts were published in the general pages of the Daily Express, embedded in the political and military war news. This was in line with the strategy of the new popular press in Britain to publish human interest stories alongside hard news to arouse the interest of the female readership. ${ }^{132}$

In conclusion, Christitch produced intimate eyewitness accounts of the appalling conditions in Serbia. Little was known about Britain's smallest ally, especially during the first months of the war. Through Christitch's writings and lectures, war-stricken Serbia became news in Britain and the wider English-speaking world. 


\section{Notes}

1. Marcel Broersma, “Transnational Journalism History: Balancing Global Universals and National Peculiarities”, Medien \& Zeit 25, no. 4 (2010): 10-15, here 10-11; Frank Bösch, Mass Media and Historical Change: Germany in International Perspective, 1400 to the Present (New York: Berghahn, 2015), 10; Marie Cronqvist and Christoph Hilgert, "Entangled Media Histories: The Value of Transnational and Transmedial Approaches in Media Historiography”, Media History 23, no. 1 (2017): 130-141, here 130.

2. Cronqvist et al., "Entangled Media Histories”, 132. The EMHIS network consists of a group of some 30 scholars from Sweden, Britain, Germany and other countries who have collaborated since 2013 to overcome the narrow national and mono-media research perspective. See ibid., 131; “About the network", https:// emhis.blogg.lu.se/about/ (accessed July 19, 2021).

3. Corinna Unger, “Transnational History Versus International History”, in The Humanities Between Global Integration and Cultural Diversity, ed. Birgit Mersmann, Hans G. Kippenberg and Owen Gurrey (Berlin: De Gruyter, 2016), 18-24, here 18, 20. For an introduction to transnational history, see Akira Iriye and PierreYves Saunier, eds., The Palgrave Dictionary of Transnational History (Basingstoke: Palgrave, 2009).

4. Michele Hilmes, “Entangled Media Histories: A Response”, Media History 23, no. 1 (2017): 142-144, here 142. Patricia Clavin ("Defining Transnationalism", Contemporary European History 14, no. 4 (2005): 421-39, here 422) similarly argues that transnationalism is above all about people: 'the social space that they inhabit, the networks they form and the ideas they exchange.'

5. Broersma, “Transnational Journalism History”, 15. See also Hilmes, “Entangled Media Histories”, 143.

6. The first ideas for this article were presented at the EMHIS Forum VIII: 'Current Challenges of Entangled Media Histories - Theories, Sources and Methodologies’, held in Gregynog, Wales, 14-16 May 2019.

7. On female cosmopolitanism and the connections between transnational and gender history, see Oliver Janz and Daniel Schönpflug, eds., Gender History in a Transnational Perspective: Networks, Biographies, Gender Orders (New York and Oxford: Berghahn, 2014); Susanne Quitmann, “The Life of Marie Munk (1885-1978): Working Across and Within National Borders as a Women’s Rights Activist”, Yearbook of Transnational History 2 (2019): 123-48.

8. Stephanie Seul, “Women War Reporters”, in 1914-1918 Online: International Encyclopedia of the First World War, ed. Ute Daniel, Peter Gatrell, Oliver Janz, Heather Jones, Jennifer Keene, Alan Kramer, and Bill Nasson, issued by Freie Universität Berlin, July 22, 2019. DOI: 10.15463/ie1418.11385.

9. Bösch, Mass Media, 53, 85 . 
10. Ibid., 85 .

11. Hamilton Fyfe, “A Wanderer in War Lands," The War Illustrated, February 16, 1918, 6-7; The History of the Times. Volume 4: The 150th Anniversary and Beyond, 1912-1948. Part I: Chapters I-XII, 1912-1920; Part II: Chapters XIII-XXIV, 1921-1948, Appendices and Index (London: Offices of The Times, 1952; reprint: Nendeln/Lichtenstein: Klaus Reprint, 1971), 230. Waterman’s articles can be found in the Times Digital Archive (available from Gale Primary Sources through university libraries), Trove (Australian newspaper archive, https://trove.nla.gov.au/, accessed July 13, 2021) and Papers Past (New Zealand newspapers, https://paperspast.natlib.govt.nz/, accessed July 13, 2021).

12. “Death of Miss Mary Billington”, Daily Telegraph, August 29, 1925, 11; Barbara Onslow, "Billington, Mary Frances (1862-1925)", in Dictionary of Nineteenth-Century Journalism in Great Britain and Ireland, ed. Laurel Brake and Marysa Demoor (Gent: Academia Press and London: The British Library, 2009): 54.

13. Tim Luckhurst, "War Correspondents", in 1914-1918 Online: International Encyclopedia of the First World War, ed. Ute Daniel, Peter Gatrell, Oliver Janz, Heather Jones, Jennifer Keene, Alan Kramer, and Bill Nasson, issued by Freie Universität Berlin, March 15, 2015, DOI: 10.15463/ie1418.10862.

14. Anne Sebba, Battling for News: Women Reporters from the Risorgimento to Tiananmen Square (London: Faber and Faber, 2013): 62.

15. For American women, see Chris Dubbs, An Unladylike Profession: American Women War Correspondents in World War I (Lincoln: Potomac Books, 2020); Carolyn Edy, The Woman War Correspondent, the U.S. Military, and the Press, 1846-1947 (Lanham: Lexington Books, 2017). The numbers for Britain, the British Empire and Europe result from my own research.

16. Stephanie Seul, "Women War Reporters".

17. Ibid.

18. “Women War Correspondents”, The Morning Call (Paterson, New Jersey), December 28, 1916, 4. On the female angle in war reporting, see Milly Buonanno, "Women War Correspondents: Does Gender Make a Difference on the Front Line?", unpublished paper, 59th Annual ICA Conference in Chicago, May 21-25, 2009, https://www.academia.edu/1859435/Women_war_correspondents_does_gender_make_a_difference_ on_the_front_lines (accessed July 19, 2021).

19. Christine Hallett, Nurse Writers of the Great War (Manchester: Manchester University Press, 2016), 5.

20. Adrian Bingham and Martin Conboy, Tabloid Century: The Popular Press in Britain, 1896 to the Present (Oxford: Peter Lang, 2015): 8-9, 28-29, 34; Kevin Williams, Read All About It! A History of the British Newspaper (London and New York: Routledge, 2010): 130-32; John M. McEwen, "The National Press 
During the First World War: Ownership and Circulation”, Journal of Contemporary History 17, no. 3 (1982): 459-486, here 461, 482; Robert Allen, Voice of Britain: The Inside Story of the Daily Express (Cambridge: Patrick Stephens, 1983): 17, 23-29.

21. Daily Express, July 1, 1918, 2.

22. Allen, Voice of Britain, 17-18.

23. Adrian Bingham, Gender, Modernity, and the Popular Press in Inter-War Britain (Oxford: Clarendon Press, 2004): 27, 29, 37; Bingham and Conboy, Tabloid Century, 131-32; Martin Conboy, Journalism: A Critical History (London: Sage, 2004): 142-43.

24. Their articles can be researched in the Daily Express archive: https://www.ukpressonline.co.uk/ ukpressonline/ (accessed July 19, 2021).

25. Bingham, Gender, Modernity, 29. On the gendering of the news in the popular press, see ibid., 23-37. Alfred Charles William Harmsworth, 1st Viscount Northcliffe (1865 - 1922), was a British newspaper magnate and owner of the Daily Mail.

26. Lara Putnam, "The Transnational and the Text-Searchable: Digitized Sources and the Shadows They Cast", American Historical Review 121, no. 2 (2016): 377-402, here 377, 380.

27. UKPressOnline: https://www.ukpressonline.co.uk/ukpressonline/; The British Newspaper Archive: https:// www.britishnewspaperarchive.co.uk/; ProQuest Historical Newspapers: https://about.proquest.com/en/ content-solutions/news/; Chronicling America: https://chroniclingamerica.loc.gov/; Newspapers.com: https://www.newspapers.com/; The Portal to Texas History: https://texashistory.unt.edu/; Papers Past: https://paperspast.natlib.govt.nz/; Trove: https://trove.nla.gov.au/ (accessed July 19, 2021).

28. John J. Burns Library, Boston College, Annie and Elizabeth O’Brien Christitch Papers, MS. 1994.039, http:// hdl.handle.net/2345.2/MS1994-039 (accessed July 19, 2021). I wish to thank the John J. Burns Library for providing me with digital copies from the Christitch papers. See also Ronald D. Patkus, "The British Catholic Authors Collection in the Burns Library at Boston College”, Catholic Archives 15 (1995): 47-56, here 52; “Centre for British Catholic writers”, The Tablet, November 12, 1983, 1105-1106.

29. “Madame Christitch”, The Tablet, February 4, 1933, 137. See also Slavica Popović Filipović, Hrabrost između redova: Ani Hristić u Srbiji i vreme odvažnih / Courage Between the Lines: Miss Annie Christitch in Serbia and the Time of the Brave (Belgrade: The Society of Serbian Historians, 2015), 445. This book - the first biography of Christitch - consists to a large extent of long verbatim quotations from memoirs and contemporary newspaper articles and is more a source collection than a historical analysis. As the work is not always correctly referenced, it should be used with caution. 
30. “A Forthright Woman”, The Tablet, July 30, 1977, 729; “Miss Annie Christitch”, The Times, June 14, 1977, 18; Short biography of Annie Christitch, undated, John J. Burns Library, Boston College, Annie and Elizabeth O’Brien Christitch Papers, MS. 1994.039, Box 1, Folder 28; Cecilia Mary Young, "Women in the News: A Catholic View" [short biography of Annie Christitch], July 13, 1931, ibid.; F.C. Burnand, The Catholic Who's Who and Year-Book 1930 (London: Burns \& Oates, 1930), 85. See also Popović Filipović, Courage, 16-17, 19.

31. “Forthright Woman”; Annie Christitch, “Geneva - 'L'Esprit Genevois'”, Ius Suffragii: The International Woman Suffrage News, May-June 1920, 297. On the Balkan Wars, see Richard C. Hall, "Balkan Wars 19121913”, in 1914-1918 Online: International Encyclopedia of the First World War, ed. Ute Daniel, Peter Gatrell, Oliver Janz, Heather Jones, Jennifer Keene, Alan Kramer, and Bill Nasson, issued by Freie Universität Berlin, October 8, 2014, DOI: 10.15463/ie1418.10009.

32. Popović Filipović, Courage, 19. For Christitch's articles see the Daily Express of October 29, 1912 (“The Women of Belgrade”, 4); October 31, 1912 (“Wounded Number Thousands”, 7); November 5, 1912 ("The Spirit of the Soldiers", 4); November 6, 1912 ("Hypochondric General”, 9); November 12, 1912 (“Conquerors as Prisoners”, 5); December 9, 1912 (“Fashions in War Time”, 6); January 7, 1913 (“Christmas in January", 4).

33. E.g., "At Belgrade”, Votes for Women, November 12, 1912, 79; “The Brain of Servia's Army”, Manchester Courier, November 15, 1912, Weekly Supplement, 2.

34. “In a Servian Hospital”, Express and Telegraph (Adelaide, Australia), December 14, 1912, 4; "Spirit of Soldiers”, Hastings Standard (New Zealand), January 20, 1913; “The Women of Belgrade”, The Omaha Sunday Bee (Nebraska, USA), December 8, 1912, Part Two. See also Popović Filipović, Courage, 165.

35. Sebba, Battling for News, 44-46; Bösch, Mass Media, 86.

36. "Forthright Woman".

37. "Miss Annie Christitch"; The Tablet, November 8, 1919, 602; Young, "Women in the News"; Burnand, Catholic Who's Who (1930), 85.

38. The Tablet, July 13, 1929, 41. See Annie Christitch, Women of the Gospel (London: Burns Oates \& Washbourn, 1929); review “Daughters of Jerusalem”, The Tablet, July 27, 1929, 107.

39. “Congress of International Woman Suffrage Alliance”, Women's Franchise, May 6, 1909, 4-7; Edith Moriarty, “With Women of Today”, The Daily Times (Davenport, Iowa), October 15, 1921, 3. See also Popović Filipović, Courage, 19.

40. Ius Suffragii: The International Woman Suffrage News, February 1920, 255-56; May-June 1920, 297; July 1920, 333, 334; August 1920, 357; The Tablet, June 5, 1920, 772. 
41. “Notes”, The Tablet, May 17, 1919, 612; “Literary Notes”, The Tablet, July 26, 1919, 107; “Miss Annie Christitch"; “The Catholic Women’s Suffrage Society in England”, The Women's Medical Journal, 27, no. 3 (March 1920), 87. Christitch's blessing from the pope for women's electors was reported around the globe, see for example the Melbourne Advocate, October 4, 1919, 4; Ithaca Daily News (New York), November 11, 1919, 5. See also Elaine Clark, “Catholic Men in Support of the Women's Suffrage Movement in England”, The Catholic Historical Review 94, no. 1 (2008): 22-44; Francis M. Mason, “The Catholic Women’s Suffrage Society in England, 1911-1923”, The Catholic Historical Review 72, no. 4 (1986): 620-638.

42. "Forthright Woman"; Young, “Women in the News”. See also Popović Filipović, Courage, 479.

43. E.g., "Half a Million Orphans Cry for Help in Serbia”, Chicago Daily Tribune, December 8, 1920, 3; “Girl from Serbia here”, St. Louis Star (Missouri), December 18, 1920, 7; “Founder of Serb Woman Movement to Lecture Here", The Albuquerque Morning Journal (New Mexico), October 18, 1921, 5; “Catholic Women Plan to Organize”, The Gazette and Daily (York, Pennsylvania), January 28, 1922, 5; Annie Christitch, "The Yugo-Slav Family Reunion”, Our World, September 1922, 35-40; Young, “Women in the News”. See also Popović Filipović, Courage, 479.

44. See e.g., "Founder of Serb Woman Movement to Lecture Here”; Edith Moriarty, "With Women of Today", The Daily Times (Davenport, Iowa), October 15, 1921, 3.

45. "Forthright Woman”; "Miss Annie Christitch"; The Catholic Transcript (Hartford, Connecticut), August 30, 1934, 2.

46. "Miss Annie Christitch"; short note in America, February 7, 1914, 429; Young, "Women in the News"; Christitch, “Geneva”; F.C. Burnand, The Catholic Who's Who and Year-Book 1920 (London: Burns \& Oates, 1920), 80; The Catholic Transcript (Hartford, Connecticut), August 30, 1934, 2. See also Popović Filipović, Courage, 24.

47. “Certificate of Naturalisation”, January 20, 1950, The National Archives, Kew, London, HO 334/334, BNA 9672.

48. "Miss Annie Christitch"; "Forthright Woman”.

49. Annie Christitch, "Gallant Little Servia”, letter to the editor, Daily Express, September 16, 1914, 4.

50. Christitch, "Geneva”.

51. Larissa Wegner, "Rear Area on the Western Front", in 1914-1918 Online: International Encyclopedia of the First World War, ed. Ute Daniel, Peter Gatrell, Oliver Janz, Heather Jones, Jennifer Keene, Alan Kramer, and Bill Nasson, issued by Freie Universität Berlin, February 12, 2016, DOI: 10.15463/ie1418.10826. 
52. Annie Christitch, "Impressions of a Woman Under Fire at the Front", Daily Express, November 19, 1914, 1.

53. Ibid.

54. Annie Christitch, “Dead Woman’s Finger?”, Daily Express, November 20, 1914, 4.

55. Annie Christitch, “Heroines of the Nursing Line”, Daily Express, November 21, 1914, 5.

56. "Presents for Nurses at the Front", Daily Express, December 3, 1914, 5.

57. “Woman Under Fire Tells Her Experience”, The Fort Wayne Daily News, December 12, 1914, 15; “Woman Enters Nieuport After Battle”, El Paso Herald, December 12, 1914, 9; “Woman Under Fire At Front”, Journal Gazette, December 17, 1914, 7; “How Woman Felt in Real Battle”, The Washington Herald, December 20, 1914, Part II, 9; "Impressions of a Woman Under Fire at the Front”, The Citizen, December 5, 1914, 12; “Women Drive Through District Under Fire”, Victoria Daily Times, December 7, 1914, 6; “Woman Under Fire”, Darling Downs Gazette, January 18, 1915, 6 (articles signed A. Christitch). Due to poor OCR, it may well be that Christitch's articles were reprinted in many more international publications.

58. "Heroines of the Nursing Line", Bendigo Advertiser (Victoria), January 14, 1915, 4; "Heroines of the Nursing Line”, Bendigonian (Bendigo, Victoria), January 19, 1915, 9 (articles signed A. Christitch).

59. Richard C. Hall, "War in the Balkans (Version 1.1)", in 1914-1918 Online: International Encyclopedia of the First World War, ed. Ute Daniel, Peter Gatrell, Oliver Janz, Heather Jones, Jennifer Keene, Alan Kramer, and Bill Nasson, issued by Freie Universität Berlin, October 8, 2014, DOI: 10.15463/ie1418.10163/1.1; Dmitar Tasić, “Warfare 1914-1918 (South East Europe)”, in ibid., October 8, 2014, DOI: 10.15463/ie1418.10366.

60. Tasić, “Warfare 1914-1918”; Mile Bjelajac, “Serbia”, in 1914-1918 Online: International Encyclopedia of the First World War, ed. Ute Daniel, Peter Gatrell, Oliver Janz, Heather Jones, Jennifer Keene, Alan Kramer, and Bill Nasson, issued by Freie Universität Berlin, October 1, 2015, DOI: 10.15463/ie1418.10737; Monica Krippner, Quality of Mercy: Women at War, Serbia 1915-18 (Newton Abbot and London: David \& Charles, 1980), 34.

61. “Scottish Women's Hospitals", The National Archives, http://www.nationalarchives.gov.uk/ womeninuniform/swh_intro.htm (accessed July 19, 2021); Angela K. Smith, British Women of the Eastern Front: War, Writing and Experience in Serbia and Russia (Manchester: Manchester University Press, 2016), 22-23; Krippner, Quality of Mercy, 33-34.

62. Smith, British Women, 60.

63. Annie Christitch, “Blacklegs of Bulgaria”, Daily Express, April 8, 1915, 4. 
64. Annie Christitch, “Britain's New Gift of Tongues”, Daily Express, April 3, 1915, 4. Reprinted in Australia: “British Nurses in Serbia”, Bendigonian (Victoria), May 27, 1915, 31.

65. Annie Christitch, “Motherless Island”, Daily Express, January 14, 1915, 4.

66. Annie Christitch, “Motherless Island”, Oamaru Mail, March 31, 1915, 7.

67. “Forthright Woman”; Annie Christitch, “Servia’s Deadliest Foe”, letter to the editor, Daily Express, March 11, 1915, 3; “Scotswomen in Serbia”, The Scotsman, March 24, 1915, 7.

68. "Visit of a Serbian Journalist”, The Falkirk Herald, March 20, 1915, 7.

69. In most of her articles, Christitch referred to 'Servia' instead of 'Serbia'. The spelling 'Servia' was commonly used by the British press prior to the First World War. It was changed to 'Serbia' during the war, as 'Servia' sounded too much like 'servility' and was considered disrespectful for an ally. In January 1915, a New York newspaper reported that the Serbian Legation in London had addressed a letter to the press and public, urging the adoption of the spelling 'Serbia' since 'Servia' 'is highly offensive to our people, mainly because it suggests a false derivation from the Latin root, meaning "to serve”. ("Serbians Object to Being Called 'Servians'”, The Brooklyn Daily Eagle, January 14, 1915, 23. See also Paul Fussell, The Great War and Modern Memory [New York: Sterling Publishing, 2009], 220). Still, Christitch and the Daily Express continued to use the spelling 'Servia' until early 1916.

70. Annie Christitch, “The Austrians in Servia”, Daily Express, March 4, 1915, 4; Annie Christitch, "Austrians in Captivity”, Sun (Christchurch), April 23, 1915, 12.

71. Annie Christitch, “Servia’s Great White City”, Daily Express, March 6, 1915, 4.

72. "Serbia’s Great White City”, The Evening Telegraph and Post, March 8, 1915, 4; "Servia's Great White City", South China Morning Post, April 23, 1915, 11; “Servia’s Great White City”, Sun (Christchurch), May 4, 1915, 12; “Servia’s Great White City”, Northern Advocate, May 10, 1915, 2; “Servia’s Great White City”, Grey River Argus, May 20, 1915, 7.

73. Annie Christitch, "Men Who Suffer in Silence”, Daily Express, March 13, 1915, 4 (reprinted in New Zealand: “Through Servian Hospitals”, Sun [Christchurch], May 24, 1915, 11; reprinted in Australia: “Men Who Suffer in Silence”, Bendigo Advertiser [Victoria], April 30, 1915, 5); Annie Christitch, “Blacklegs of Bulgaria”, Daily Express, April 8, 1915, 4 (reprinted in New Zealand: “Blacklecs [sic] of Bulgaria”, Oamaru Mail, May 27, 1915, 2); “The Crisis in Serbia”, The Falkirk Herald, March 27, 1915, 3.

74. Fortier Jones, With Serbia into Exile: An American's Adventures with the Army That Cannot Die (New York: Grosset \& Dunlap, 1916), 84.

75. Annie Christitch, “The ‘Liberation’ of Valjevo”, Daily Express, March 5, 1915, 4. 
76. E.g., “Desolate Servia”, Sun (Christchurch, New Zealand), April 28, 1915, 10; “The War”, Feilding Star (New Zealand), April 30, 1915, 4; “A Stricken Town”, Scrutineer and Berrima District Press (New South Wales, Australia), May 5, 1915, 4; “A Stricken Town”, Scone Advocate (New South Wales, Australia), May 7, 1915, 6. In total I found nine reprints of Christitch's article.

77. Annie Christitch, “Serbian Womanhood”, Church League for Woman's Suffrage, July 1915, 123; “Serbia”, Sevenoaks Chronicle and Kentish Advertiser, April 23, 1915, 5.

78. Annie Christitch, “Servia’s Call for Help”, Daily Express, May 21, 1915, 7.

79. Annie Christitch, “Servia's Need”, letter to the editor, Daily Express, March 13, 1915, 9. See also Annie Christitch, “Gifts for Servia”, letter to the editor, Daily Express, March 16, 1915, 2.

80. Annie Christitch, “Servia’s Deadliest Foe”, letter to the editor, Daily Express, March 11, 1915, 3.

81. Annie Christitch, “Hundred Beds for Servia”, Daily Express, March 23, 1915, 9; Annie Christitch, “The Egg Tappers”, Daily Express, April 10, 1915, 7; Annie Christitch, “Servia’s Call for Help”, Daily Express, May 21, $1915,7$.

82. E.g., "Call for Aid From Servia”, Daily Express, March 24, 1915, 6; "Help for Servia”, Daily Express, March 30, $1915,7$.

83. See “'Daily Express’ Valjevo Fund”, Daily Express, April 20, 1915, 8; “'Daily Express’ Valjevo Fund” Daily Express, February 24, 1916, 6.

84. “Nurses’ Prize-Day”, Daily Express, March 11, 1915, 2; “Stage Allies”, Daily Express, March 17, 1915, 6; “The Needs of Serbia”, The Tablet, May 1, 1915, 565; Norwood News, May 7, 1915, 5; "What Some of Our Societies are Doing", The Common Cause, June 18, 1915, 151.

85. Leeds: "Notes and Comments", The Yorkshire Post, April 20, 1915, 6; Sevenoaks: "Serbia”, Sevenoaks Chronicle and Kentish Advertiser, April 23, 1915, 5; “The Week”, ibid., April 30, 1915, 5; “Suffering Serbians”, Kent Messenger, May 1, 1915, 8; Haywards Heath, Sussex: “Serbia and the War”, Mid-Sussex Times, April 27, 1915, 8.

86. “Conditions in Serbia”, The Derry Journal, April 14, 1915, 8; “Suffering Serbia”, Londonderry Sentinel, April $15,1915,3$. Christitch recounted her experience of travelling to Ireland as a foreigner in war-time: Annie Christitch, “The Alien Who Was an Ally”, Daily Express, April 17, 1915, 4.

87. Perth: “Scottish Women's Hospital”, The Perthshire Constitutional \& Journal, March 22, 1915, 5; Dundee: “Scottish Hospital Units”, The Courier, March 20, 1915, 4; Edinburgh: "Scotswomen in Serbia”, The Scotsman, March 24, 1915, 7; Falkirk: "The Crisis in Serbia”, The Falkirk Herald, March 27, 1915, 3; "Serbia”, The Falkirk Herald, May 1, 1915, 5; “Plague-Stricken Serbia”, ibid., May 5, 1915. 
88. “The Needs of Serbia”, The Tablet, May 1, 1915, 565. On the lanterns see also the announcement of Christitch’s lecture in the Perthshire Advertiser and Strathmore Journal, March 17, 1915, 1.

89. "Serbia", The Falkirk Herald, May 1, 1915, 5.

90. “Notes and Comments", Yorkshire Post, April 20, 1915, 6.

91. "Serbia and the War”, The Mid-Sussex Times, April 27, 1915, 8.

92. E.g., "Scottish Women's Hospital”, The Perthshire Constitutional \& Journal, March 22, 1915, 5; "Scotswomen in Serbia”, The Scotsman, March 24, 1915, 7; “The Crisis in Serbia”, The Falkirk Herald, March 27, 1915, 3; “Conditions in Serbia”, The Derry Journal, April 14, 1915, 8; “Serbia and the War”, The Mid-Sussex Times, April 27, 1915, 8; “Jottings of the Day”, Falkirk Herald, May 8, 1915, 4.

93. “Ravaged by Fever”, The Times of India, May 21, 1915, 15.

94. “Social News and Gossip”, Catholic Press (Sydney), July 1, 1915, 356.

95. Annie Christitch, “Servia’s Call for Help”, Daily Express, May 21, 1915, 7; “Nurse Wounded”, Daily Express, December 23, 1915, 6; “Over Mountain Passes”, Birmingham Gazette, December 24, 1915, 8; Jones, With Serbia, 84. The mission is briefly mentioned in Krippner, Quality of Mercy, 38.

96. Annie Christitch, "Through France in Wartime”, Daily Express, June 2, 1915, 4; Annie Christitch, “Through Grecian Waters”, Daily Express, June 17, 1915, 4.

97. Annie Christitch, “Shirts Better Than Wine”, Daily Express, July 8, 1915, 4.

98. Ibid.

99. “Over Mountain Passes”. The article recounted the experiences of Miss Spooner, a nurse in Christitch’s unit.

100. Annie Christitch, "Serbian Girl Describes the Austrian Yoke”, The Detroit Free Press, November 24, 1918, Part Four, 1; The Catholic World, December 1921, 431; Young, "Women in the News".

101. Sybil Eden, “Fighting Death in Servia”, Daily Express, December 24, 1915, 5. On Sybil Eden, see Jones, With Serbia, 4; "Millions in Bullion and Securities on Tuscania", The Indianapolis News, January 18, 1916, 1.

102. Annie Christitch, “How Young Servia Lends a Hand”, Daily Express, September 23, 1915, 4.

103. Annie Christitch, "In Battered Vishegrad", Daily Express, October 22, 1915, 4; "In Battered Vishegrad", Oamaru Mail, December 7, 1915, 8.

104. Hall, "War in the Balkans”; Tasić, "Warfare 1914-1918”; Bjelajac, "Serbia”.

105. The American Fortier Jones, a member of the Columbia University Relief Expedition who had joined the 'Christitch Unit' in Valjevo in early October, describes the unit and its evacuation during the advance of the 
Austro-Hungarian and German forces in his book With Serbia into Exile. For reviews, see The Nation, October 5, 1916, 328-29; The Evening Post (New York), October 5, 1916, 8.

106. “Over Mountain Passes”, Birmingham Gazette, December 24, 1915, 8; "Epic of the Flight from Serbia”, Daily Express, December 23, 1915, 1; Sybil Eden, “Fighting Death in Servia”, Daily Express, December 24, 1915, 5; “Miss Christitch”, Daily Express, January 3, 1916, 3; “Thrilling Experiences in Serbia”, The Luton Reporter, January 3, 1916, 8; “Straight from Serbia”, The Luton Reporter, January 10, 1916, 5; “Notes”, The Tablet, January 8, 1916, 43; Christitch, “Serbian Girl Describes the Austrian Yoke”, Part Four, 3. See also Young, "Women in the News"; Jones, With Serbia, 109.

107. Christitch, “Serbian Girl Describes the Austrian Yoke”, Part Four, 3. See also Annie Christitch, “Our Three Years in Serbia”, Daily Express, July 1, 1918, 2; Annie Christitch, “My Life in Serbia”, Daily Express, October 1, 1918, 2. In February 1916, R.D. Blumenfeld, the editor of the Daily Express, asked the British Foreign Office for permission to telegraph $£ 250$ to Switzerland for Miss Christitch, who wished to pay off debts in connection with her hospital work in Serbia. A gentleman was going from Switzerland into Serbia and was to carry the money through. Although authority was given to forward the money to Switzerland for remittance to Christitch in Serbia, it is not clear whether Christitch ever received it. See "Remittance of $£ 250$ to Serbia”, The National Archives, Kew, London, FO 383/131, papers no. 24910, 30141, 34906 (February 1916).

108. Christitch, "Our Three Years in Serbia”.

109. Christitch, "Serbian Girl Describes the Austrian Yoke", Part Four, 3. See also Christitch, "Our Three Years in Serbia”; "Forthright Woman"; Short biography of Annie Christitch, undated; Young, "Women in the News".

110. Annie Christitch, “Relieving Want in Servia”, Belfast Telegraph, December 4, 1918, 2; Annie Christitch, “Westminster Cathedral Revisited", The Tablet, November 9, 1918, 512-13.

111. Annie Christitch, "Little Nation With a Great Heart", Daily Express, June 26, 1918, 2; reprinted in Maryborough and Dunolly Advertiser (Victoria), September 2, 1918, 4; Bendigonian (Victoria), September 5, 1918, 2; Riverine Herald (Echuca, Victoria, and Moama, New South Wales), September 30, 1918, 4.

112. Christitch, “Our Three Years in Serbia”; “In Serbia”, Feilding Star, September 4, 1918, 4; “Our Three Years in Serbia”, Wanganui Chronicle, September 21, 1918, 6; “Three Years in Serbia”, Ashburton Guardian, September 25, 1918, 7 .

113. “The Queen of Valjevo”, Daily Express, June 25, 1918, 2.

114. “Super-Profiteers in Vienna”, Daily Express, September 24, 1918, 3; reprinted in the Irish Waterford Standard, September 28, 1918, 4. 
115. Annie Christitch, “Will You Help Serbia?”, Daily Express, September 30, 1918, 2.

116. Annie Christitch, “My Life in Serbia”, Daily Express, October 1, 1918, 2.

117. Annie Christitch, “My Experiences in Serbia”, Daily Express, October 2, 1918, 2.

118. Annie Christitch, “Risking Life for Bread”, Daily Express, October 4, 1918, 2.

119. Annie Christitch, “Serbian Women’s Ordeal”, Daily Express, November 26, 1918, 4.

120. Annie Christitch, "War Time Wear in Serbia”, Daily Express, December 13, 1918, 3; Annie Christitch, “Bread Like Mud Pies”, Daily Express, December 20, 1918, 3.

121. Christitch, "Westminster Cathedral Revisited”.

122. "Some Regular Features", The Atlanta Constitution, January 4, 1918, 9; short note in The Washington Times, November 10, 1918, 17; “Italian General Lauds American Valor in Battle”, The Atlanta Constitution, December 10, 1918, 2; George Seldes, Witness to a Century: Encounters with the Noted, the Notorious, and the SOBs (New York: Ballantine Books, 1987), 63-65.

123. Annie Christitch, "Relieving Want in Servia”, Belfast Telegraph, December 4, 1918, 1; Annie Christitch, “Serbian Girl Describes the Austrian Yoke”, The Detroit Free Press, November 24, 1918, Part Four, 1, 3; Annie Christitch, “Woman Saved Many Lives When Serbian Nation Was Overrun by Austrians”, St. Louis Globe-Democrat, November 29, 1918, 1; Annie Christitch, "Three Years Under the Austrian Yoke”, San Antonio Express (Texas), November 24, 1918, 21-22. Another article was published in the Pittsburgh Gazette Times on December 1, 1918, but apparently the pages are not digitised on Newspapers.com. See the announcement of Christitch's article in The Gazette Times, November 30, $1918,9$.

124. Christitch, "Geneva”.

125. New Zealand Tablet, March 20, 1924, 37.

126. “Girl from Serbia Here”, St. Louis Star (Missouri), December 18, 1920, 7.

127. "Forthright Woman".

128. The Times and the Daily Mail are available from Gale Primary Sources through university libraries and the Daily Express through UKPressOnline: https://www.ukpressonline.co.uk/ukpressonline/ (accessed July 19, 2021). On Olive Dent, see Samraghni Bonnerjee, “'The Lure of War’: Reconsidering the Motivations of Nurses to Volunteer in the First World War", Women's History Review 28, vol. 7 (2019): 1096-1114. On F. Tennyson Jesse, see Joanna Colenbrander, A Portrait of Fryn: A Biography of F. Tennyson Jesse (London: A. Deutsch, 1984). On Louise Mack, see 
Jeannine Baker, Australian Women War Reporters: Boer War to Vietnam (Coogee: NewSouth Publishing, 2015).

129. On Sinclair, see Sara Prieto, “'Without Methods'. Three Female Authors Visiting the Western Front”, First World War Studies 6, no. 2 (2015): 171-185; Bonnerjee, "Lure of War".

130. Simon J. Potter, "Webs, Networks, and Systems: Globalization and the Mass Media in the Nineteenth- and Twentieth-Century British Empire”, Journal of British Studies 46, no. 3 (2007): 621-646; Simon J. Potter, News and the British World: The Emergence of an Imperial Press System 1876-1922 (Oxford: Oxford University Press, 2003).

131. Hallett, Nurse Writers, 5.

132. Bingham, Gender, Modernity, 23, 29, 37.

\section{Biography}

Stephanie Seul is a researcher at Deutsche Presseforschung, Department of Cultural Studies, University of Bremen, and a Fellow of the Royal Historical Society. Her research focuses on the intersection between international/transnational history and the history of media and communication in the era of the two World Wars. Her writing has appeared in numerous edited volumes and journals, including the Leo Baeck Institute Year Book; Jewish Historical Studies; Politics, Religion \& Ideology; Media History; Journal of Modern Italian Studies; and 1914-1918 Online. 


\section{TMG Journal for Media History}

Volume 24 No $(1 / 2) / 2021$

\section{DOI}

https://dx.doi.org/10.18146/tmg.791

\section{PUBLISHER}

Netherlands Institute for Sound and Vision

\section{COPYRIGHT}

Each article is copyrighted (c) by its author(s) and is published under license from the author(s). When a paper is accepted for publication, authors will be requested to agree with the Creative Commons Attribution 4.0 International License. 